\title{
IBSI Education "SIWESI" Quality Measurement Based on System Technical Viewpoint
}

\author{
Sindi Dwi Putri $S^{a}$

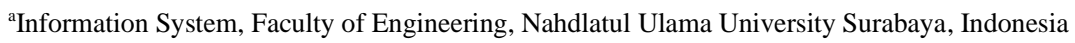

\begin{abstract}
A B S T R A C T
The need for information systems is increasing every year. The information system of an organization or company is useful for managing data to produce useful and effective information that supports activities and all levels of management that use it. The aspect of software quality is one of the important things in the development of a software. To determine the quality of software products, a measurement is needed. IBSI Education, one of which is a Tutoring Institution that uses "SiWeSi" to support administration, view schedules, see student progress, and so on. The success of the software that is built is based on whether or not the software works according to the objectives to be achieved. In the scientific concept of software engineering, the success of software is not only seen from the suitability of the resulting product to existing needs. The success of the software is also seen from the software development process. This study uses the McCall quality model because this method fulfills many components of the assessment and looks at quality from the user's point of view. The quality model used to measure the quality of SIWESI is determined from the results of the literature study.
\end{abstract}

Keywords: Quality Measurement, SiWeSi, IBSI Education, McCall.

Article History

Received 07 July 20

Received in revised form 25 July 21

Accepted 26 July 21

\section{Introduction}

The aspect of software quality is one of the important things in the development of a software. To determine the quality of software products, a measurement is needed. Quality measurement involves variables, instruments, and standards. the measurement results of some metrics are directly proportional to the software quality and some other metrics measurement results are inversely proportional to the quality. Metrics that are directly proportional to software quality are function points, Software Maturity Index (SMI), and portability metrics. While the other metrics used are inversely proportional to the measurement of software quality, so to normalize it, subtraction is used to the number 1 . [1][2][3]

Information systems within an organization or company are useful for managing data to produce useful and effective information that supports activities and all levels of management that use [4][5][6]. IBSI Education is a tutoring institution that offers private lessons, group lessons, and classroom lessons. This tutoring institution was established around 2014 and at that time there was no system to control the tutors and the tutoring institution itself.

IBSI Education, one of which is a Tutoring Institution that uses "SiWeSi" to support administration, view schedules, see student progress, and so on. Moreover, "SiWeSi" itself will be used to run business processes in tutoring institutions, so a quality measurement is needed. Which is the quality to be measured from the point of view of technical and system users. This scientific article intends to find out the quality level of "SiWeSi" IBSI Education with deficiencies and recommendations for improvement.

Software quality is needed in system development. Quality will affect the performance of the software. Software quality is the fulfillment of documented functionality and performance requirements. In order for the software to have good performance, it is necessary to properly explore user needs. A product has good quality if it can satisfy most of its users. Software quality assurance is important because it will provide information for management to determine product quality. Quality products can provide certainty and confidence that products can meet quality goals [7].

Software measurement is important because the quality of the system will be known after the measurement, whether the quality of the system is in the good or bad category. One of the testing methods is testing based on McCall's theory of quality [8][9][10]. McCall is a software testing method that has the most complete and in-depth criteria (Product Operation) with five quality factors of correctness, usability, reliability, integrity and efficiency [11][12].

The results of the research in the form of the percentage of the quality of the IBSI Education information system based on user perceptions using the McCall method are expected to provide benefits in the form of information to determine the level of software quality and software utilization based on McCall's theory, so that it can be input and advice for institutions in improving the system in the future. to increase user utilization as expected.

\footnotetext{
* Corresponding author.

E-mail address: sindi.spentisa@gmail.com
} 
Measuring the quality of an information system is very important to do to find out how the current condition of the information system itself is, whether it is still relevant or not with the current conditions, if after the measurement it turns out that the information system is no longer relevant then it can be used as a reference or reference for improvements to make it more efficient. good again.

\section{Literature Review}

Usability is a measure, where users can operate and use the software without requiring a lot of practice [13]. Usability measurement is determined by two factors, namely: Operability and Training. Operability is the suitability of operating system usage by end-users. Training is the level at which the software can be used by new users. This assessment can be obtained through the analysis of the end-user observation questionnaire [14]. Besides McCall, for usability measurement there is also a Cognitive Walkthrough method. However, this method focuses more on measuring the suitability between the interface design and the application's business processes [15].

McCall's method has been widely used to measure the usability of applications in various fields. Mulyanto (2016) also used McCall to measure the quality of the Academic Information System at a university including design, specifications and coding and obtained good results of $72.68 \%$ [16]. Research conducted by Hidayati, et al. in 2017, using the McCall method on the Academic Information System (SIAK) of a polytechnic, the results obtained that the usability factor was able to meet user needs of $65.3 \%$ [8]. Research conducted by Arif, et al. Also using the McCall method to measure the usability of the bonus system in a company with a result of $74.72 \%$ which indicates the usability of the bonus system in that company is good [17].

This study aims to analyze usability to measure the level, where a product can be used by certain users to achieve their goals more effectively, efficiently, and satisfy Tokopedia web application users. This research is descriptive qualitative using the McCall framework. The research instrument was in the form of a questionnaire as a way of collecting data which would later be analyzed using McCall's quality standards.

From previous research, it can be known what factors are the benchmarks or references for measuring the quality of an information system, Product Operations (Operational characteristics) with five factors used to assess accuracy, reliability, efficiency, usability and integrity, methods McCall has become one of the references for several previous researchers to test the quality of an information system because this method is considered sufficient to meet several aspects of the criteria needed to test the quality of an information system and has proven its reliability. From previous research conducted with the McCall method. The tests carried out only focus on the usability factor on the operational character of McCall's theory, so further research needs to be done for other factors so that the quality assurance of information system software has a better quality value [10].

\subsection{Measurement technique}

According to Presman, the measurement technique using the McCall method is difficult, and in some cases it is not possible to develop direct measures on quality factors. Therefore, a set of metrics is defined and used to develop expressions for each factor according to the relationship.

1. Measurement Scale

According to Atep Afia Hidayat, et al, scale is a measure that is arranged in such a way that it can sort respondents in a more precise size based on certain variables. The measurement scale that is often used is as follows: Likert scale.

Likert scale is a measurement scale used to measure attitudes, opinions and perceptions of a person or group about social events or phenomena. This social phenomenon has been specifically defined by the researcher, hereinafter referred to as the research variable. The Likert scale makes the variables to be measured are translated into dimensions, dimensions are translated into sub-variables then sub-variables are then translated back into indicators that can be measured. These measurable indicators can be used as a starting point for making instrument items in the form of questions or statements that need to be answered by respondents. Each answer is associated with a form of question or attitude support expressed in words. The Likert scale is used to obtain data on the software validity test. The Likert scale is used to measure the validity factor of the beta test software. The Likert scale will later be used to test the quality factors of correctness, reliability, integrity, usability and efficiency.

\subsection{Understanding Information Systems}

An information system is a system within an organization that brings together the daily transaction processing needs that support the managerial functions of the organization's operations with the strategic activities of an organization in order to provide certain outside parties with the necessary reports[10].

1. The benefits of having an internal information system an agency, namely:

a) Presenting information to support decision making.

b) Presenting information to support daily operations.

c) Presenting information related to management.

2. Some components of information systems can be classified as follows:

a) Hardware and software that function as machines.

b) Humans (people) and procedures (procedures) which are humans and procedures for using machines.

c) Data is a bridge between humans and machines so that a data processing process occurs.

\subsection{McCall. method}

McCall's method is a model that describes Software Quality Factor or software quality. This model has three main perspectives, namely product operation (operational properties of software), product revision (software ability to undergo changes), and product transition (software adaptability to new environments). Product operation includes several factors, namely correctness, reliability, usability, integrity, and usability. This method contains the most complete software quality criteria or factors. Because the McCall method has good accuracy and detail so that it can be used to test and guarantee the quality of information system software[10]. 


\subsection{Quality Concept}

In the perspective of TQM (Total Quality Management) quality is seen more broadly, namely not only as an emphasized result but also includes processes, the environment and people. Meanwhile, according to Gaspers (1997), "quality management can be said as all activities of the overall management function that determine quality policies, objectives and responsibilities, and implement them through quality management tools, such as quality planning, quality control, quality assurance". While the definition formulated by Goeth and Davis (1995), "that quality is a dynamic condition associated with products, services, people, processes, and the environment that meet or exceed expectations". On the other hand, according to Lukman (1999), "the definition of quality varies from controversial to more strategic". Therefore, quality in principle is to keep customer promises so that the parties served are satisfied and expressed so that quality has a very close relationship with customer satisfaction.

\section{Research Methods}

This study uses a research methodology as shown in Figure 1. The first stage is to determine the quality model by conducting a literature review of the quality model so as to obtain the appropriate model. The next step is to conduct quality testing by applying a predetermined quality model. The next stage is to discuss the results of quality testing so as to obtain the desired results.

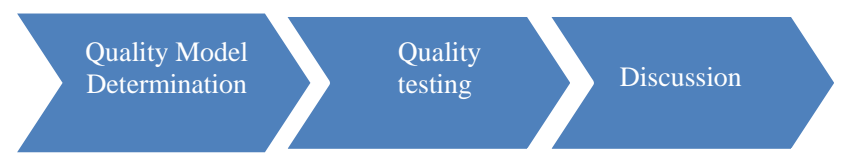

Figure 1. Research Methods

The quality model is the quality of the characteristics and the relationship between the elements. Quality methods determine quality requirements and evaluate quality. Comparison of several quality models such as McCall, Boehm[18], dromey[19], FURPS[20], BBN, Star, dan ISO 9126[21]. The results show that McCall's quality model satisfies many components of the assessment and sees quality from the user's point of view. The quality model used to measure the quality of SIWESI is determined from the results of the literature study.

After determining the quality model, then the quality testing stage, measurements are carried out by measuring at each point of view. At this stage, the parties involved in testing are also determined.

\section{Result and Discussion}

The implementation of the test is detailed in the test on the technical perspective of the system by the user. This test is seen from several factors that are tested using tools such as Page Speed.

\subsection{Efficiency}

To test the efficiency factor, it is done using an online page speed tool. This

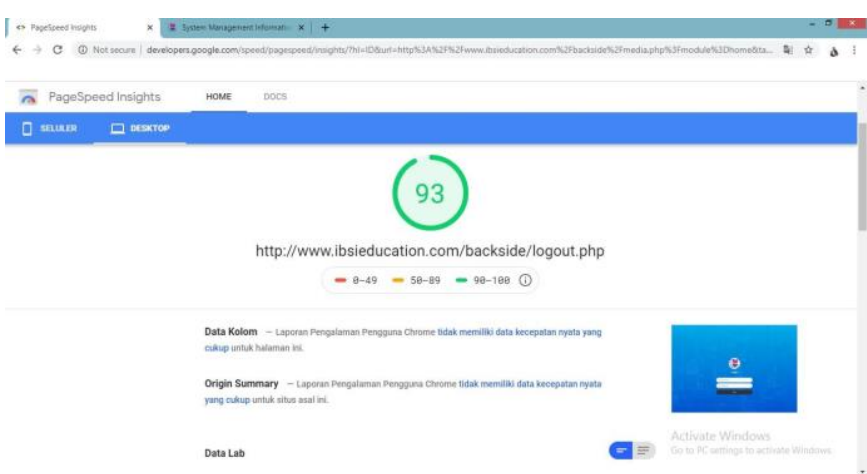

tool is a Google feature that provides facilities to analyze the performance of website page speed with a score. The results of the efficiency test are presented in Figure 2 and Figure 3

Figure 2. Page Speed Test Results

Based on the test results in Figure 2, it is known that the speed of www.ibsieducation.com is in the fast category with a value of 93. This speed is for the desktop version. The time it takes for SIWESI to display the main content of the page and become fully interactive is 0.7 seconds. While the SIWESI speed index, which is how fast the page content looks complete, is 1.1 seconds. In addition to the speed for displaying information, the online page speed also provides information about the potential delay in the first input that the user may experience, which is 20 $\mathrm{ms}$. In addition to the results from the desktop version, the online page speed can also show the speed performance on the mobile version. According to Figure 3, SIWESI is known to enter the category a bit slow with a value of 73 . This value is slightly less good than the desktop version.

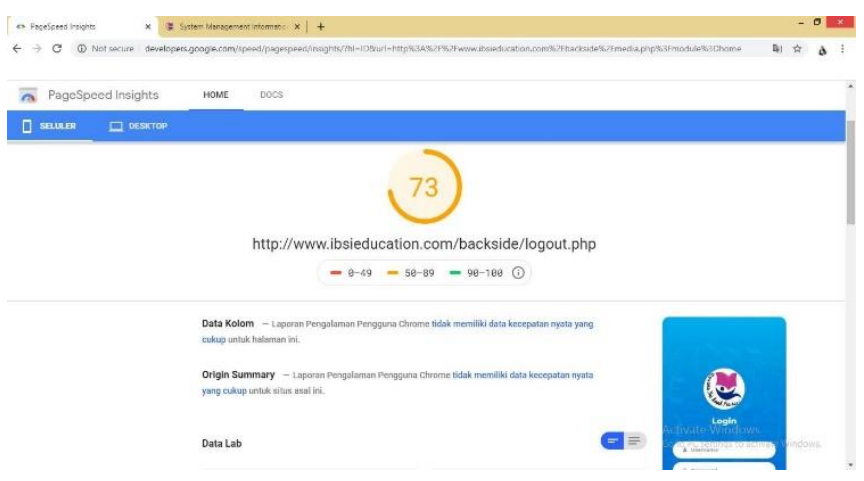

Figure 3. Page Speed Test Results

\subsection{Portability}

For testing on the portability factor using desktop and mobile devices with multiple browsers. The details of the test are presented in the table below. 
Table 1. Table of Portability Factor Testing Details.

\begin{tabular}{lcc}
\hline Device & Laptop & Smartphone \\
\hline Browser & & \\
\hline Google Chrome & V & V \\
Mozilla Firefox & V & V \\
\hline
\end{tabular}

This result is also related to the access point, SIWESI functionality is the same. It's just that for the printing process, because of the different settings in the Mozilla and Google Chrome browsers, access is easier on the Google Chrome browser. However, for functional printing, both can be done

\section{Conclusion}

Based on the results of the quality measurement viewed from the technical perspective of the system by the user, the following conclusions are obtained:

Technically, SIWESI's quality is good with the following details:

a) Of the 5 menus, there is 1 menu that is not fully needed, yesterday's honorarium for which the menu was only used to see the amount of last month's honorarium.

b) The efficiency of SIWESI is fast with a value of 93 for desktop and a bit slow 73 for mobile.

\section{REFERENCES}

[1] J. Kh, S. Iskandar, K. Badak, T. Sereal, K. Bogor, and J. Barat, "Pengukuran Kualitas Perangkat Lunak Sistem E-Learning Menggunakan Metric Function Oriented," Pros. SNATIF, vol. 4, pp. 769-776, 2017.

[2] M. S. Ritzkal, "Pengukuran Kualitas Perangkat Lunak Sistem Manajemen Pelaporan Kegiatan Berbasis Web Peringatan Berbasis Email," Semin. Nas. TEKNOKA, vol. 2, no. 2502, pp. 75-80, 2017.

[3] F. R. Hariri and J. E. W. Prakasa, "Pengukuran Kompleksitas Sistem E-Learning di UIN Maulana Malik Ibrahim Malang Menggunakan Metrik Function Oriented," Semin. Nas. Infovasi Teknol. UN PGRI Kediri, pp. 245-250, 2019.

[4] Z. Munawaroh, M. Mudhofi, and D. Susanto, "Efektivitas Sistem Informasi Dan Komputerisasi Haji Terpadu (Siskohat) Dalam Penyelenggaraan Ibadah Haji," J. Ilmu Dakwah, vol. 35, no. 2, p. 225, 2017, doi: 10.21580/jid.v35i2.1608.

[5] D. Anggoro and A. Hidayat, "Rancang Bangun Sistem Informasi Perpustakaan Sekolah Berbasis Web Guna Meningkatkan Efektivitas Layanan Pustakawan," Edumatic $J$. Pendidik. Inform., vol. 4, no. 1, pp. 151-160, 2020, doi: 10.29408/edumatic.v4i1.2130.

[6] Apriyansyah, I. Maullidina, and E. P. Purnomo, "Efektivitas Sistem Informasi Desa (SID) Dalam Pelayanan Publik Di Desa Dlingo, Kecamatan Dlingo, Kabupaten Bantul," J. Anal. Kebijak. dan Pelayanan Publik, vol. 4, no. 1, pp. 10-24, 2018,
[Online]. Available: journal.unhas.ac.id/index.php/jakpp. R. B. H. Eti Kapita, M. Angelin, and S. R. Wicaksono, "ANALISIS KUALITAS PERANGKAT LUNAK MENGGUNAKAN METODE FUNCTION POINT ANALYSIS (STUDY KASUS: Transaksi Pembelian di eBay)," J. Inform. dan Rekayasa Perangkat Lunak, vol. 1, no. 1, pp. 3136, 2019, doi: 10.36499/jinrpl.v1i1.2764.

[8] A. Hidayati, E. Oktariza, F. Rosmaningsih, and S. A. Lathifah, "Analisa Kualitas Perangkat Lunak Sistem Informasi Akademik Menggunakan McCall," Multinetics, vol. 3, no. 1, p. 48, 2017, doi: 10.32722/multinetics.vol3.no.1.2017.pp.48-53.

[9] H. Hanes, A. Angela, and S. S. Br, "Pengukuran Kualitas Website Penjualan Tiket Dengan Menggunakan Metode Mccall," J. Tek. Inform. Kaputama, vol. 4, no. 2, pp. 81-88, 2020.

[10] Khairullah, B. Soedijono, and H. Al Fatta, "Pengukuran Kualitas Sistem Informasi Inventaris Aset Universitas Muhammadiyah Bengkulu Menggunakan Metode MCCALL," Inf. Interaktif, vol. 2, no. 2, pp. 84-92, 2017.

[11] I. D. Lestantri and R. Rosini, "Evaluation of Software Quality to Improve Application Performance Using Mc Call Model," J. Inf. Syst. Eng. Bus. Intell., vol. 4, no. 1, p. 18, 2018, doi: 10.20473/jisebi.4.1.18-24.

[12] T. Gondewa, S. F. Utami, and S. R. Widianto, "Evaluasi Kualitas Sistem Informasi Manajemen Rumah Sakit Menggunakan Metode McCall," KURAWAL J. Teknol. Inf. dan Ind., vol. 3, no. 1, pp. 58-65, 2020.

[13] D. Galin, Software Quality Assurance From Theory to Implementation. England: Pearson Education Limited, 2004.

[14] R. S. Pressman, "Rekayasa Perangkat Lunak: Pendekatan Praktisi Edisi 7 - Buku Satu,” Andi, 2010.

[15] P. Raharjo, W. A. Kusuma, and H. Sukoco, "Uji Usability Dengan Metode Cognitive Walkthrough Pada Situs Web Perpustakaan," J. Pustak. Indones., vol. 15, no. 1, pp. 19-27, 2016.

[16] A. Mulyanto, "Pengujian sistem informasi akademik menggunakan Mccall's software quality framework," JISKA (Jurnal Inform. Sunan Kalijaga), vol. 1, no. 1, pp. 47-57, 2016.

[17] M. U. Siregar and A. H. Arif, "A Usage of McCall's Software Quality Analysis on the Bonus System of PT Surya Pratama Alam," JISKA (Jurnal Inform. Sunan Kalijaga), vol. 3, no. 1, p. 63, 2018, doi: 10.14421/jiska.2018.31-07.

[18] M. Andryan, W. Saputra, W. A. Rioditama, and H. Setyowati, "Survei Teknik-Teknik Pengukuran Kualitas Perangkat Lunak," vol. 3, no. 1, pp. 2715-2731, 2021.

[19] T. R. Hadi, "Komparasi Kualitas sebuah Sistem Informasi pada Website Staff Perguruan Tinggi UNY dan UNS," no. April, pp. $1-6,2015$.

[20] S. Anugrah and A. Eka Putra, "Analisis Kualitas ISO 25010 Aplikasi Artificial Intelligence Troubleshooting Komputer dengan FURPS," e-Tech J. Ilm. Teknol. Pendidik., vol. 6, no. 2, 2019, [Online]. Available: http://ejournal.unp.ac.id/index.php/e- 
tech/article/view/101342.

[21]

L. A. A. R. Prawita, Wayan Gede Suka Parwita and Putri,

"Komponen Penilaian Kualitas Perangkat Lunak berdasarkan
Software Quality Models," Semin. Nas. Teknol. Inf. Komun.

Terap. 2012 (Semantik 2012), vol. 2012, no. Semantik, pp. 8994, 2012. 